\title{
Keterlibatan Orangtua dalam Pendampingan Belajar Anak selama Masa Pandemi Covid-19
}

\author{
Wiwin Yulianingsih ${ }^{\bowtie}$, Suhanadji $^{2}$, Rivo Nugroho ${ }^{3}$, Mustakim ${ }^{4}$ \\ Pendidikan Luar Sekolah, Universitas Negeri Surabaya $(1,2,3)$ \\ Pendidikan Islam Anak Usia Dini, Universitas Muhammadiyah Gresik (4) \\ DOI: $\underline{10.31004 / \text { obsesi.v5i2.740 }}$
}

\begin{abstract}
Abstrak
Kebijakan pemerintah untuk belajar dari rumah selama masa pandemi Covid-19 membuat orang tua semakin banyak terlibat dalam pendampingan anak. Tujuan penelitian ini untuk mengukur peran orang tua selama anak belajar dari rumah, dan mengukur tingkat pendampingan belajar anak yang dilakukan orang tua selama masa pandemi. Pendekatan kuantitatif dilakukan dengan teknik statistik deskriptif, dan sampel penelitian sebanyak 40 orang tua peserta didik PAUD SKB Cerme Gresik. Teknik pengambilan sampel dilakukan dengan proportional random sampling, serta analisis data dengan descriptive statics frequencies dan persentase. Uji validitas menggunakan korelasi product moment dan Uji reliabilitas menggunakan Alfa Cronbach. Dari hasil penelitian dapat disimpulkan bahwa orang tua memiliki peran sebagai pembelajar anak, pemenuh kebutuhan anak, pemahaman spiritual, pengawasan, motivasi, dan penyedia fasilitas anak. Pendampingan belajar anak terlihat dari cara orang tua membantu kesulitan tugas anak, menjelaskan materi yang tidak dimengerti anak, dan merespon dengan baik semua pembelajaran daring dari sekolah.

Kata Kunci: pendampingan; orang tua; belajar dari rumah.
\end{abstract}

\begin{abstract}
The government policy to learn from home during the covid-19 pandemic made parents more involved in assisting children. The purpose of this study was to measure the role of parents during children's learning from home, and to measure the level of children's learning assistance carried out by parents during the pandemic. The quantitative approach used is descriptive statistical techniques, with a sample of 40 parents of kindergarten's students in skb (learning activity center) cerme gresik. The sampling technique used was proportional random sampling, while the data analysis technique used was descriptive statics frequencies and percentages. The validity test used is the product moment correlation, and the reliability test used is cronbach's alfa. From the results it can be concluded that parents have a role as child teachers, child needs providers, spiritual teachers, supervisors, motivators, and child facilities providers. Children's learning assistance can be seen from the way parents help children's task difficulties, explain material that children do not understand, and respond well to all online learning from school.
\end{abstract}

Keywords: mentoring; parents; learning from home.

Copyright (c) 2020 Wiwin Yulianingsih, Suhanadji, Rivo Nugroho, Mustakim

$\triangle$ Corresponding author:

Email Address: wiwinyulianingsih@unesa.ac.id (Jln. Colombo No. 1, Karang Malang, Yogyakarta)

Received 31 August 2020, Accepted 8 October 2020, Published 15 October 2020 


\section{PENDAHULUAN}

Penyakit mematikan yang melanda seluruh dunia sebagai bencana non-alamyakni Covid-19 yang disebabkan oleh virus Corona atau Severe acute respiratory syndrome coronavirus 2 (SARS-CoV-2) (Lai et al., 2020). Wabah ini berasal dari Wuhan, Provinsi Hubai China yang kemudian secara perlahan menyebar ke seluruh dunia dengan nama 2019-nCoV (Chen et al., 2020; Huang et al., 2020). Penyebaran Covid-19 di Indonesia selama kurun waktu Desember 2019-Februari 2020 tidak ada kasus infeksi, namun pada 2 April 2020 dua kasus pertama terkonfirmasi Infeksi Covid-19 (Djalante et al., 2020). Berdasarkan informasi dari Kementerian Kesehatan RI, pada 25 April 2020 perkembangan jumlah kasus terkonfirmasi positif Covid-19 di Indonesia menjadi 8.607 kasus. Dari kasus tersebut 1.042 sembuh dan 720 meninggal (Achmad, 2020). Melihat banyaknya jumlah tersebut membuat pemerintah menggencarkan program dan kebijakannya agar penyebaran Covid-19 dapat dikendalikan. $\mathrm{Hal}$ ini membuat pemerintah harus bergerak cepat memutus rantai penyebaran Covid-19.

Kebijakan yang dibuat pemerintah untuk menanggulangi penyebaran Covid-19 diantaranya pembatasan aktivitas, himbauan untuk selalu menjaga kebersihan diri, social distancing, physical distancing, karantina wilayah, bekerja di rumah bagi karyawan, hingga pembatasan mobilitas manusia dari wilayah ke wilayah lainnya (BBC, 2020). Adanya Covid19 juga menuntut adanya perubahan dalam pembelajaran. Berdasarkan data United Nations Educational, Scientific and Cultural Organization (UNESCO), pada 18 Maret jumlah negara yang telah menerapkan pembelajaran daring mencapai 112 negara (Yovita, 2020).

Pemerintah Indonesia telah mengupayakan berbagai kebijakan untuk meningkatkan kewaspadaan terutama dalam hal mencegah penyebaran kasus, diantaranya: mulai dari menerapkan kebijakan bekerja dan belajar dari rumah hingga mengajukan pembatasan sosial berskala besar (PSBB). Hal ini turut dilakukan oleh beberapa wilayah di Indonesia untuk mencegah penyebaran Covid-19, salah satunya di provinsi Jawa Timur. Surat Edaran Gubernur Jawa Timur Nomor 420/5952/436.7.1/2020 perihal Peningkatan Kewaspadaan Terhadap Covid-19, Gubernur telah menetapkan 16 butir yang harus diperhatikan oleh masyarakat, salah satu butir diantaranya terkait pelaksanaan proses pembelajaran dalam jaringan (daring) (Dian, 2020). Walikota Surabaya juga mengeluarkan Surat Edaran Nomor 360/3324/436.8.4/2020 perihal Peningkatan Kewaspadaan Terhadap Covid-19 di Surabaya yang salah satunya memberlakukan pembelajaran jarak jauh (PJJ) atau belajar dari rumah (BDR) melalui media daring bagi peserta didik pada satuan pendidikan (PAUD/TK, SD, SMP. LKP, LPK dan PKBM) dibawah kewenangan Pemerintah Kota Surabaya (Pebriansyah, 2020). Pelaksanaan belajar dari rumah juga mengalami perpanjangan, awalnya para pelajar dihimbau untuk belajar di rumah mulai tanggal 16-20 Maret 2020, kemudian diperpanjang satu pekan lagi dari 23-28 Maret 2020 yang ditandatangani Kepala Dinas Pendidikan Kota Surabaya. Dengan adanya kebijakan ini, seluruh instansi pendidikan di Jawa Timur, khususnya di Kabupaten Gresik juga tunduk dan harus mematuhi isi dari kebijakan tersebut.

Program belajar dari rumah dilaksanakan secara mandiri di rumah masing-masing. Adanya kebijakan tersebut membuat orangtua kembali lagi menguatkan perannya untuk menjadi pendidik pertama dan utama bagi anak. Keluarga sebagai lembaga pendidikan informal dilindungi dalam Undang-undang No. 20 tahun 2003 tentang Sistem Pendidikan Nasional (Sisdiknas, 2003). Keluarga adalah lembaga pendidikan yang pertama dan utama, manajemen orang tua dalam memberikan pendidikan anak di dalam rumah, di sekolah dan dimasyarakat menjadi tujuan keberhasilan akademis anak (Gutman \& Mcloyd, 2000; Slameto, 2010). Oleh karena itu, keluarga mempunyai peranan penting dalam mempersipakan pendidikan anak untuk mewujudkan cita-cinyata. Pendidikan keluarga adalah proses seumur hidup yang berlangsung sepanjang masa, sehingga setiap orang memperoleh nilai, sikap, keterampilan dan pengetahuan yang berasal dari pengalaman hidup sehari-hari, pengaruh lingkungan termasuk pengaruh kehidupan keluarga, hubungan dengan tetangga, lingkungan kerja dan bermain, pasar, perpustakaan dan media massa (Sudjana, 2004). Anak-anak dapat 
memperoleh pendidikan keluarga maksimal jika orangtua ingin berbagi pengalaman mereka sebelumnya dengan anak-anak.

Ki Hajar Dewantara mengatakan bahwa pendidikan keluarga menempatkan sifat dan manifestasi yang lebih sempurna daripada pusat-pusat lain, untuk maju menuju pendidikan karakter intelijen (pembentukan karakter individu) dan membuat ketentuan untuk kehidupan sosial (Dewantara, 1961). Sikap intelijen di sini adalah salah satu bentuk penanaman dasar agama pada anak-anak. Suasana kehidupan keluarga adalah tempat terbaik untuk melakukan pendidikan pribadi (pendidikan individual) dan pendidikan sosial. Keluarga adalah tempat yang sempurna untuk mewujudkan fungsi pendidikan dalam pembentukan diri seseorang, perkembangan kognitif, dan perkembangan neurokognitif anak (Noble et al., 2015). Dengan demikian, peran keluarga tidak dapat tergantikan meskipun anak telah belajar di lembaga pendidikan formal maupun nonformal. Sebagai pengasuh dan pembimbing dalam keluarga, meletakkan dasar-dasar perilaku bagi anak, sikap, perilaku, dan kebiasaan orangtua akan selalu dilihat, dinilai, dan ditiru oleh anak (Baumrind, 1978). Sikap orangtua ini meliputi cara orangtua memberikan aturan-aturan/hadiah/hukuman, cara orangtua menunjukkan otoritasnya, dan cara orangtua memberikan perhatian serta tanggapan terhadap anaknya (Agustin, 2015).

Adanya kebijakan dari pemerintah terkait memaksimalkan aktivitas kegiatan di rumah juga semakin memurnikan dan menguatkan kembali peran keluarga dalam bidang pendidikan. Orangtua memiliki peran penting dalam mendidik anak, memberiksn keterampilan kognitif, edukasi kesehatan mental dan fisik, serta peningkatan kualitas kesehatan psikologis keluarga (Mann et al., 2004; Wyatt Kaminski et al., 2008). Sebelum adanya himbauan untuk memaksimalkan aktivitas di rumah, aktivitas masih dilakukan secara normal dan rumah adalah sebagai tempat kembali dari kegiatan sehari-hari. Dengan adanya himbauan ini, peran orangtua benar-benar dimurnikan kembali sebagai pendidik, keterlibatan orang tua dalam pengawasan kegiatan belajar, sumber belajar utama bagi anak, otoritas orang tua memberikan pengajaran kepada anak sesuai materi dari guru, dan menjalankan perannya sebagai guru pengganti selama kegiatan belajar dari rumah (Epstein \& Becker, 2018).

Kegiatan belajar dari rumah diselenggarakan secara daring (dalam jaringan). Kegiatan belajar anak tersebut dilaksanakan di rumah dan menjadi tanggungjawab orangtua. Kesiapan belajar dari rumah ini dapat dilihat dari bagaimana orangtua dalam membimbing anak selama belajar di rumah. Tidak semua orangtua siap menjalankan pekerjaan rumah sekaligus menjadi guru pengganti selama BDR. Contoh sederhana yaitu guru memberikan tugas melalui grup WhatsApp atau melalui aplikasi Google Classroom atau melalui platform Google Meet, Google Zoom, dan sebagainya untuk mengintegrasikan teknologi dalam proses belajar mengajar virtual (Okmawati \& Tanjak, 2011). Tugas diberikan guru secara harian sesuai jadwal mata pelajaran dan jam pelajaran tertentu. Peserta didik kemudian mengerjakan secara mandiri di rumah begitu pula untuk hari-hari berikutnya. Namun yang pasti harus dilakukan adalah pemberian tugas melalui pemantauan dan pendampingan oleh guru, sehingga anak benarbenar belajar. Kemudian guru juga bekerja dari rumah dengan berkoordinasi dengan orangtua, bisa melalui video call maupun foto kegiatan belajar anak di rumah untuk memastikan adanya interaksi antara guru dengan orangtua, dengan dukungan internet yang memadai (A. Purwanto et al., 2020). Adanya pembelajaran daring menambah tugas orangtua yang juga menjadi guru di rumah. Keterlibatan orang tua yaitu suatu proses orangtua untuk mengerahkan kemampuannya untuk keperluan dirinya, anak, dan program yang dilaksanakan oleh sang anak (Patmodewo, 2003). Dengan keterlibatan orangtua menjadi alternatif yang dapat digunakan untuk meningkatkan kerjasama pendidik dan orangtua serta meningkatkan peran orangtua.

Kebanyakan orangtua menganggap keterlibatan mereka dalam pendidikan anak hanya sebatas menanggung biaya, menyediakan infrastruktur dan berbagai keperluan materi lainnya. Dalam konteks pendidikan, keterlibatan orangtua harus merangkumi satu lingkup yang lebih luas daripada pembiayaan semata. Keterlibatan orangtua dalam lembaga 
pendidikan dapat dilakukan melalui berbagai upaya antara lain sebagai pendidik, pengamat proses pembelajaran di kelas, tenaga sukarela, maupun pengambil kebijakan di sekolah. Beberapa alasan yang mendasari pentingnya keterlibatan orangtua dalam pendidikan adalah dapat mengkomunikasikan dengan baik kepada orang tua tentang kegiatan yang dilakukan oleh anak. Selain itu juga berkontribusi terhadap pencapaian tugas perkembangan anak, baik dalam aspek kognitif maupun aspek perkembangan lainnya (Diadha, 2015). Berdasarkan paparan tersebut, maka tujuan penelitian ini adalah untuk menggambarkan keterlibatan orangtua keterlibatan orangtua dalam pendampingan belajar anak selama masa pandemi Covid-19 di PAUD SKB Cerme Gresik.

\section{Kajian Teori}

Keterlibatan orangtua sangat penting karena memberikan pengaruh yang besar terhadap keberhasilan anak. Dengan keterlibatan orang tua maka, akan membantu anak dalam perkembangan literasi, intelektual, motivasi, dan prestasi (menheere \& hooge, 2010). Namun sebaliknya, jika anak tanpa arahan dan bimbingan dari orangtua tidak akan bisa berjalan dengan sendirinya. Dengan adanya keterlibatan orangtua, anak akan mendapatkan pengalaman-pengalaman yang akan terinternalisasi menjadi kepribadian anak(akbar, 2017). Keterlibatan orangtua merupakan alternatif yang dapat digunakan untuk meningkatkan kerjasama pendidik dan orangtua selama pandemi covid-19. Dampak dari adanya program bdr adalah orangtua yang dituntut untuk melakukan pendampingan kepada anak selama belajar dari rumah. Hal ini membuat tidak sedikit orangtua perlu meluangkan waktunya demi dapat membantu proses pembelajaran anaknya selama di rumah. Beberapa diantaranya juga yang merasa hal ini menjadi tambahan aktivitas orangtua selain mengerjakan pekerjaan rumah tangga serta menjadi tantangan tersendiri untuk menggantikan peran guru di sekolah (haerudin et al., 2020).

Selama pandemi covid-19, keterbatasan sangat dirasakan dalam berbagai hal termasuk pembatasan pertemuan sistem persekolahan yang mengharuskan persekolahan dilaksanakan secara daring. Alternatif pembelajaran online yang memberikan kemudahan dalam belajar jarak jauh, seperti tv sekolah, zoom, slack, google meet, dan platform edupage (basilaia \& kvavadze, 2020). Semua alternatif media pembelajaran yang dilakukan tersebut menggunakan bantuan internet. Manfaat dari penggunaan media ini diharapkan mampu menarik perhatian siswa dan memudahkan siswa dalam memahami materi (a. E. Purwanto \& hendri, 2016). Menurut hasil survei apjii 2018 mengenai pengguna internet sebagai berikut:

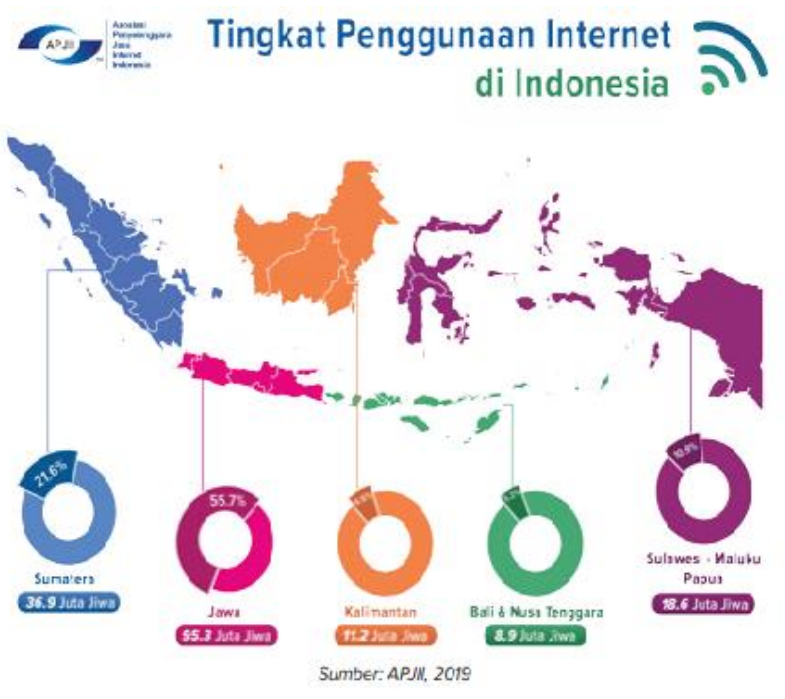

Gambar 1. Tingkat Penggunaan Internet 
Dari data tersebut, penggunaan internet cukup sangat membantu dalam bidang politik, budaya, pariwisata, agama, kesehatan, pendidikan dan hiburan. Penggunaan internet terutama aplikasi media daring berdampak pula pada pola pendidikan, kesehatan dan pariwisata (kementerian komunikasi dan informatika ri, 2019). Dalam masa pandemi ini, pembelajara yang dilakukan di sistem persekolahan sebagian besar menggunakan sistem belajar secara daring (dalam jaringan)/virtual. Menurut isman (w. A. F. Dewi, 2020) pembelajaran daring merupakan pemanfaatan jaringan internet dalam proses pembelajaran. Dengan pembelajaran daring siswa memiliki keleluasaan waktu belajar, dapat belajar kapanpun dan dimanapun. Siswa dapat berinteraksi dengan guru menggunakan beberapa aplikasi seperti classroom, video converence, telepon atau live chat, zoom maupun melalui whatsapp group. Pembelajaran ini merupakan inovasi pendidikan untuk menjawab tantangan akan ketersediaan sumber belajar yang variatif. Keberhasilan dari suatu model ataupun media pembelajaran tergantung dari karakteristik peserta didiknya. Sebagai mana yang diungkapkan oleh nakayama bahwa dari semua literatur dalam elearning mengindikasikan bahwa tidak semua peserta didik akan sukses dalam pembelajaran online. Ini dikarenakan faktor lingkungan belajar dan karakteristik peserta didik (w. A. F. Dewi, 2020).

Orangtua merupakan sosok yang intensitas pertemuannya paling intens dengan anak, sehingga pendampingan orangtua sangat diperlukan sebagai koordinasi guru dengan orang tua saat anak belajar dari rumah (epstein \& becker, 2018). Orangtua seyogyanya mengajarkan kepada anak tentang cara mengatasi permasalahannya sendiri (suyadi, 2010). Beberapa karakteristik pembelajaran daring diantaranya: constuctivism, social constructivism, community of learners, virtual class, dan perilakuinteraktivitas, kemandirian, aksesibilitas serta pengayaan (ditjen gtk, 2016).

\section{METODOLOGI}

Penelitian ini menggunakan pendekatan kuantitatif dengan teknik analisis data statistik deskriptif. Penelitian deskriptif bermaksud mendeskripsikan secara terstruktur terkait realitas yang ada terhadap populasi tertentu serta untuk memberikan jawaban atas suatu masalah dan/atau mendapatkan informasi mendalam terkait fenomena dengan menggunakan metode penelitian pendekatan kuantitatif (Yusuf, 2016). Dalam penelitian ini yaitu mendeskripsikan keterlibatan orangtua dalam pendampingan terhadap belajar anak selama masa Belajar dari Rumah di PAUD SKB Cerme Gresik. Berikut merupakan alur pada penelitian ini:

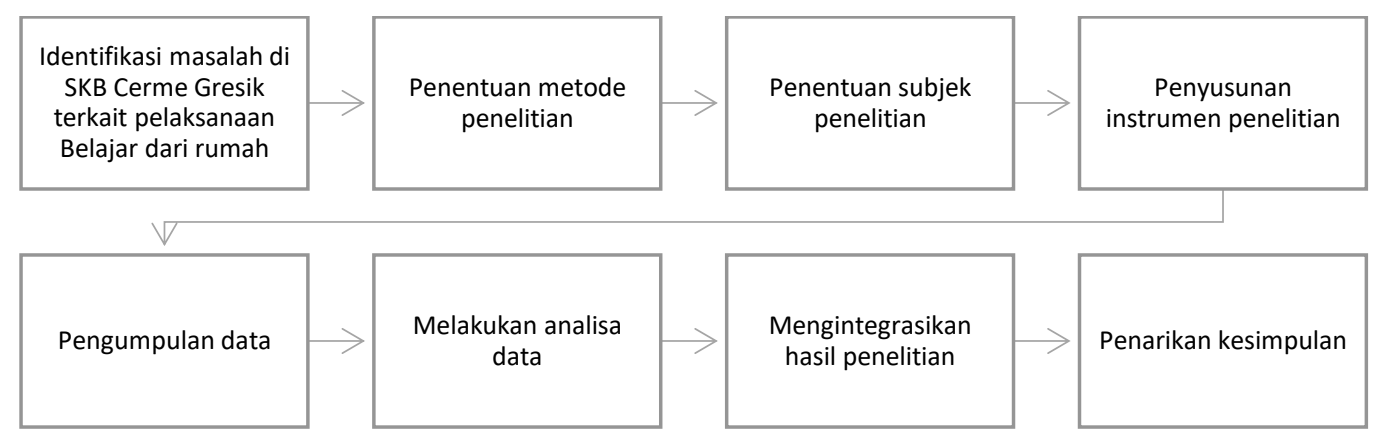

\section{Gambar 2. Alur Penelitian}

Sumber data pada penelitian ini terdapat dua sumber data yaitu data primer dan data sekunder. Data primer yaitu diperoleh dari hasil distribusi angket pada responden melalui platform google form dan data sekunder yaitu berupa dokumen dari PAUD SKB Cerme Gresik berupa data sosiodemografi yang mencakup identitas peserta didik dan orangtua. Populasi penelitian yaitu orangtua dari peserta didik di PAUD SKB Cerme Gresik yang berjumlah 40 orang. Pengambilan sampel pada penelitian ini menggunakan total sampling yaitu teknik pengambilan sampel dimana jumlah sampel sama dengan populasi (Sugiyono, 2017). Peneliti 
mengambil semua populasi sebanyak 40 orang sebagai sampel, mengingat jumlah populasi kurang dari 100. Sebagaimana paparan apabila subyeknya kurang dari 100, lebih baik diambil semua sehingga memakai penelitian populasi (Arikunto, 2010).

Instrumen penelitian ini menggunakan skala likert untuk mendapatkan hasil data yang akurat karena pilihan jawaban pada setiap item memiliki tingkatan nilai dari sangat positif hingga sangat negatif ataupun sebaliknya. Skala likert untuk mengukur pendapat, persepsi, dan sikap seseorang atau sekelompok orang tentang fenomena sosial (Sudaryono, 2014).

Tabel 1. Pemberian Skor pada Alternatif Jawaban

\begin{tabular}{ccc}
\hline Alternatif Jawaban & Kode & Nilai Skala \\
\hline Selalu & SL & 4 \\
Sering & SR & 3 \\
Jarang & JR & 2 \\
Tidak Pernah & T & 1 \\
\hline
\end{tabular}

Penelitian ini menggunakan angket tertutup yang mana dalam pengisiannya sudah disediakan pilihan jawaban sehingga responden cukup memberi tanda check list pada pilihan jawaban yang sudah tersedia pada angket melalui platform Google Form. Sebagai jajak pendapat responden terkait keadaan yang yang sedang diteliti.

Instrumen penelitian ini dikembangkan dari indikator-indikator pada sub variabel. Variabel peran orangtua didasarkan pada (Martsiswati \& Suryono, 2014b) mencakup beberapa indikator diantaranya: mengungkapkan cinta dan kasih sayang, mendengarkan anak, membantu anak merasa aman, mengajarkan aturan dan batasan, memuji anak, menghindari kritikan dengan berfokus pada perilaku, selalu konsisten untuk mendampingi anak, berperan sebagai model, dan meluangkan waktu untuk anak dan memberi pemahaman spiritual. Sedangkan variabel pendampingan belajar anak didasarkan pada Benjamin S. Bloom (1956) (dalam Gunawan \& Palupi, 2016) dengan muatan indikator kognitif, afektif, dan psikomotorik.

Analisis yang digunakan yaitu descriptive statics menggunakan bantuan SPSS 22.0. Hal ini digunakan untuk menelaah variabel pada penelitian yaitu keterlibatan orangtua dalam pendampingan terhadap belajar anak selama masa Belajar dari Rumah di PAUD SKB Cerme Gresik. Jawaban dari responden dianalisis menggunakan rumus persentase sebagai berikut:

$$
\mathrm{P}=\frac{f}{N} \times 100 \%
$$

Keterangan:

f $\quad$ : frekuensi

$\mathrm{N} \quad$ : jumlah keseluruhan responden

$\mathrm{P} \quad$ : angka persentase

Kemudian dianalisis menggunakan rumus persentase di atas dengan menggunakan tolok ukur kategori persentase sebagai berikut.

Tabel 2. Kriteria Keterlibatan Orangtua dalam Pendampingan Anak selama Belajar dari Rumah

\begin{tabular}{cc}
\hline Persentase Jawaban & Klasifikasi \\
\hline $81 \%-100 \%$ & Sangat Baik \\
$61 \%-80 \%$ & Baik \\
$41 \%-60 \%$ & Cukup Baik \\
$21 \%-40 \%$ & Kurang Baik \\
$0 \%-20 \%$ & Sangat Kurang Baik \\
\hline
\end{tabular}




\section{HASIL DAN PEMBAHASAN}

Keterlibatan orangtua dalam pendampingan terhadap belajar anak selama masa pandemic Covid-19 di PAUD SKB Cerme Gresik sangat baik dengan hasil persentase sebesar $82,79 \%$. Hal tersebut didukung dengan adanya keterkaitan hasil pada setiap sub variabel yang dijadikan sebagai indikator sebagai berikut:

\section{Peran Orangtua}

Berdasarkan hasil penelitian pada sub variabel peran orangtua sangat baik dengan persentase sebesar $83,13 \%$. Hal tersebut didukung dengan adanya kesesuaian jawaban pada sub variabel peran orangtua. Berikut adalah tabel distribusi persentase jawaban sub variabel peran orangtua.

Tabel 3. Persentase Jawaban Sub Variabel Peran Orangtua

\begin{tabular}{llll}
\hline No. & Pilihan Jawaban & Frekuensi & Persentase \\
\hline 1. & Tidak Pernah & 33 & $5,89 \%$ \\
2. & Jarang & 90 & $16,07 \%$ \\
3. & Sering & 99 & $17,68 \%$ \\
4. & Selalu & 338 & $60,36 \%$ \\
\hline Total & & $\mathbf{5 6 0}$ & $\mathbf{1 0 0} \%$ \\
\hline
\end{tabular}

Berdasarkan tabel 3. diketahui sebagian besar orangtua memilih "selalu" dengan persentase $60,36 \%$. Dalam hal ini dapat disimpulkan bahwa pada sub variabel peran orangtua lebih banyak memilih selalu. Dengan demikian dilihat dari banyaknya orangtua yang memilih selalu dapat dikatakan bahwa peran orangtua sangat penting dalam mendukung kegiatan pendampingan terhadap belajar anak selama belajar dari rumah.

Berdasarkan hasil analisis data bahwa orangtua di PAUD SKB Cerme Gresik selalu berperan dalam pendampingan anak. Dibuktikan dengan jawaban orangtua di PAUD SKB Cerme Gresik yang lebih banyak memilih jawaban selalu. Peran orangtua adalah perilaku yang yang berkenaan dengan orangtua dalam memegang posisi tertentu dalam lembaga keluarga dan berfungsi sebagai pembimbing, pengasuh, dan pendidik bagi anak serta mendukung kebutuhan sosial dan emosinal anak (Novrinda, Nina Kurniah, 2017; Peterson et al., 2010). Dalam hal ini, orangtua adalah sosok yang paling mengenal sebaik-baiknya anak belajar. Pada penelitian ini disebutkan bahwa peran orangtua diantaranya ikut serta dalam pembelajaran anak, menjelaskan dan memberikan contoh serta model dalam pembelajaran, dan memenuhi kebutuhan belajar anak, memberikan pemahaman spiritual, mengawasi proses belajar anak, memotivasi dan memberikan semangat anak, memberikan bimbingan belajar, memberikan apresiasi, menyediakan fasilitas dan kebutuhan anak dalam belajar, membantu menyelesaikan masalah anak, memberikan pengajaran di waktu yang sesuai.

Hasil penelitian ini sesuai dengan peran orangtua bagi anak adalah sebagai fasilitator, motivator, pembimbing, pendidik, dan pelindung (Fitroturrohmah \& Azizah, 2019). Orangtua yang baik adalah orangtua yang mengungkapkan cinta dan kasih sayang, mendengarkan anak, membantu anak merasa aman, mengajarkan aturan dan batasan, memuji anak, menghindari kritikan dengan berfokus pada perilaku, selalu konsisten, berperan sebagai model, meluangkan waktu untuk anak dan memberi pemahaman spiritual (Martsiswati \& Suryono, 2014a). Secara prinsip, orangtua bertanggung jawab untuk memelihara, mendidik dan melindungi anak.

Hasil penelitian ini juga sejalan dengan hasil penelitian sebelumnya bahwa selama belajar dari rumah sebagai alternatif pembelajaran di tengah pandemi Covid-19, secara umum peran orangtua adalah sebagai pembimbing, pendidik, penjaga, pengembang, dan pengawas. Secara spesifik menunjukkan bahwa peran orangtua adalah menjaga untuk memastikan anak mampu menerapkan hidup sehat, mendampingi anak dalam mengerjakan tugas, melakukan kegiatan bersama selama di rumah, menciptakan lingkungan yang nyaman untuk anak, 
menjalin komunikasi yang intens dengan anak, menjadi role model bagi anak, bermain bersama anak, memberikan pengawasan pada anggota keluarga, dan membimbing dan memotivasi anak, memberikan edukasi, memelihara nilai keagamaan, melakukan variasi dan inovasi kegiatan di rumah, serta menafkahi dan memenuhi kebutuhan keluarga (Hollingworth et al., 2011; Kurniati et al., 2020). Trisnawati \& Sugito (2020), di masa pandemi Covid-19 memberikan tanggung jawab kepada orang tua untuk menjadi pendidik utama bagi anak. Orang tua bertugas sebagai pendamping anak dalam mengerjakan tugas yaitu dengan cara membantu anak mengerjakan tugas, belajar dari lingkungan sekitar, dan memberikan pengetahuan kepada anak mengenai Covid-19.

Peran orangtua terhadap anak meliputi pendampingan pada anak, menjalin komunikasi yang baik, memberikan kesempatan atau kepercayaan, memberikan pengawasan agar anak tetap dalam pengawasan dan arahan yang baik, memberikan motivasi, mengarahkan anak serta memberikan pengasuhan dan pembelajaran yang efektif (Ingram et al., 2015). Friedman (dalam Slameto, 2010) menguraikan bahwa peranan orangtua dalam sangat dipengaruhi oleh beberapa faktor, antara lain: (a) status sosial yang ditentukan oleh tingkat pendidikan, pekerjaan, dan penghasilan; (b) bentuk keluarga; (c) tahap perkembangan keluarga dimulai dari terjadinya pernikahan hingga tahap persiapan menjadi orangtua; dan (d) faktor model peran.

\section{Pendampingan Belajar Anak}

Berdasarkan hasil penelitian pada sub variabel pendampingan belajar anak sangat baik dengan persentase sebesar $82,59 \%$. Hal tersebut didukung dengan adanya kesesuaian jawaban pada sub variabel pendampingan belajar anak. Berikut adalah tabel distribusi persentase jawaban sub variabel pendampingan belajar anak.

Tabel 4. Persentase Jawaban Sub Variabel Pendampingan Belajar Anak

\begin{tabular}{llll}
\hline No. & Pilihan Jawaban & Frekuensi & Persentase \\
\hline 1. & Tidak Pernah & 1 & $0,36 \%$ \\
2. & Jarang & 58 & $20,71 \%$ \\
3. & Sering & 76 & $27,14 \%$ \\
4. & Selalu & 145 & $51,79 \%$ \\
\hline Total & & $\mathbf{2 8 0}$ & $\mathbf{1 0 0} \%$ \\
\hline
\end{tabular}

Berdasarkan tabel 4. diketahui sebagian besar orangtua memilih "Selalu" dengan persentase $51,79 \%$. Dalam hal ini dapat disimpulkan bahwa pada sub variabel pendampingan belajar anak lebih banyak memilih selalu. Maka, dengan demikian dilihat dari banyaknya orangtua yang memilih selalu dapat dikatakan bahwa pendampingan belajar anak sangat penting dalam mendukung kegiatan belajar anak selama belajar dari rumah.

Berdasarkan hasil analisis data bahwa pendampingan belajar pada anak di PAUD SKB Cerme Gresik selalu dilakukan oleh orangtua. Dibuktikan dengan jawaban orangtua di PAUD SKB Cerme Gresik yang lebih banyak memilih jawaban selalu. Pendampingan merupakan suatu aktivitas yang dilakukan melalui pembinaan, pengajaran, pengarahan dalam individu atau kelompok. Belajar merupakan satu faktor yang berperan penting dalam pembentukan pribadi dan perilaku individu (Abtokhi, 2012). Istilah pendampingan belajar berkaitan erat dengan proses dan hasil belajar anak, karena pendampingan diartikan bimbingan yang sifatnya lebih dekat dengan subjek yang dituju terutama dalam hal perkembangan belajar anak (Retno, 2013).

Pendampingan yang diberikan oleh orangtua di rumah dapat meningkatkan motivasi belajar anak (Kurniati et al., 2020). Pendampingan disebut upaya yang dilakukan pendidik baik secara individual maupun secara kolaboratif bagi pertumbuhan serta perkembangan anak. Fungsi pendampingan belajar guna mendukung dan memberikan nilai kepuasan psikologis 
pada anak sehingga anak lebih senang belajar, tidak mengalami kejenuhan dan meminimalkan gangguan-gangguan belajar yang bisa muncul di kemudian hari. Semakin intens pendampingan belajar orangtua kepada anak, maka hasil belajar yang diraihnya akan lebih baik, dan sebaliknya semakin kurang pendampingan yang dilakukan orangtua maka hasil belajarnya kurang baik pula (Retno, 2013).

Pada penelitian ini disebutkan bahwa pendampingan belajar anak meliputi membantu mengerjakan tugas anak, sebagai tempat belajar anak, menerangkan dan memberikan penjelasan mengenai materi yang dilaksanakan, memberikan respon yang baik terhadap pembelajaran dari sekolah. Pendampingan belajar dapat membentuk karakter anak yang mampu mengerjakan tugas yang telah diperintahkan dari sekolah, mampu mempraktekan pembelajaran di rumah, dan tanggap dalam menciptakan karya sebagai implementasi pembelajaran. Hal ini sesuai dengan paparan bahwa pendampingan anak di dalam keluarga diwujudkan melalui pendidikan kiat orangtua dalam mendidik anak sehingga menjadi pribadi yang lebih baik secara pertumbuhan dan perkembangan (Mauanah, 2016).

Pendampingan yang dilakukan orangtua kepada anak antara lain pendampingan terhadap perilaku, pendampingan dalam bersikap, pendampingan dalam berbicara, pendampingan beribadah, dan pendampingan dalam belajar (Apriliana, 2017). Bentuk-bentuk pendampingan tersebut sejalan dengan yang dilaksanakan oleh orangtua peserta didik di SKB Cerme Gresik juga diantaranya membangun rasa empati, memberi kepercayaan, memberikan contoh yang baik, memberi rasa tanggung jawab, dan penghargaan maupun penguatan. Cara pendampingan belajar anak tersebut ditentukan oleh beberapa faktor. Faktor pendukung kegiatan pendampingan orangtua terhadap anak yaitu kesabaran, partisipasi anak, dan kemitraan terjalin dengan baik. Sedangkan beberapa faktor yang menghambat kegiatan pendampingan yakni jadwal kegiatan pendampingan kurang teratur, motivasi anak, minimnya dukungan, dan kurangnya variasi dalam kegiatan dan lingkungan sekitar anak.

Hasil penelitian ini juga sejalan dengan hasil penelitian lain yang menyatakan bahwa banyak dari orangtua yang turut membantu dan memberikan motivasi pada anak selama belajar dari rumah karena himbauan pemerintah mengenai Covid-19 (Haerudin et al., 2020). Hal ini juga yang membuat tidak sedikit orangtua yang sengaja untuk meluangkan waktunya demi dapat membantu proses pembelajaran anaknya selama di rumah. Banyak dari orangtua yang setuju jika selama pembelajaran di rumah, orangtua juga ikut membantu mengerjakan tugas yang diberikan oleh guru. Walaupun tidak sedikit yang merasa hal ini menjadi tambahan aktivitas orangtua selain mengerjakan pekerjaan rumah tangga. Dalam hal ini, mendampingi anak belajar dari rumah menjadi tantangan tersendiri. Di sisi lain, banyak orangtua yang menilai bahwa melalui pembelajaran di rumah dapat mempererat hubungan dengan anak. Orangtua merasa melalui pembelajaran di rumah dapat melihat perkembangan anak dalam belajar. Terlihat dalam hal ini bahwa orangtua memiliki peran yang sangat besar selama terjadinya kegiatan pembelajaran di rumah.

Lilawati (2020) menyebutkan bahwa peran orang tua dalam melakukan pembelajaran dari rumah juga ditentukan oleh beberapa faktor seperti pendidikan, pekerjaan dan pendapatan orang tua. Berdasarkan hasil penelitian yang diperoleh dari hasil dokumentasi berupa sosiodemografi disebutkan bahwa secara umum orangtua di PAUD SKB Cerme Gresik ditinjau dari segi usia sebanyak $60 \%$ berusia 20-29 tahun. Hasil ini sebanding apabila ditinjau dari segi pekerjaan yang mayoritas sebagai buruh pabrik dengan persentase $60 \%$. Sedangkan dari tingkat pendidikan sebesar $80 \%$ adalah SMA/Sederajat.

\section{SIMPULAN}

Keterlibatan orangtua dalam pendampingan anak selama belajar dari rumah (BDR) di PAUD SKB Cerme Gresik menunjukkan hasil sangat baik. Hasil tersebut didukung dengan adanya kesesuaian hasil pada setiap sub variabel yaitu pada sub variabel peran orangtua dan pendampingan belajar anak. Pendampingan dilakukan dengan cara membantu mengerjakan tugas anak, sebagai tempat belajar anak, menerangkan dan memberikan penjelasan mengenai 
materi yang dipelajari, memberikan respon yang baik terhadap pembelajaran dari sekolah. Pendampingan diharapkan dapat membentuk karakter anak yang mampu mengerjakan tugas yang telah diperintahkan dari sekolah, mampu mempraktikkan pembelajaran di rumah, dan tanggap dalam menciptakan karya sebagai implementasi pembelajaran.

\section{UCAPAN TERIMA KASIH}

Ucapan terima kasih disampaikan kepada pimpinan Fakultas Ilmu Pendidikan Universitas Negeri Surabaya atas kesempatan kami tim peneliti memperoleh Penelitian ini dan kepala SKB kabupaten Gresik, beserta staf, para guru paud, serta orangtua wali murid yang telah membantu pelaksanaan dan kesuksesan Penelitian BDR.

\section{DAFTAR PUSTAKA}

Abtokhi, A. (2012). Peran Ibu Dalam Kegiatan Pendampingan Belajar Anak Melalui Prinsip Individual Learning-Centered. Egalita, IV, 168-177. https://doi.org/10.18860/egalita.v0i0.1993

Achmad, Y. (2020). UPDATE 25 April: Kasus Covid-19 di Indonesia Mencapai 8.607. Kompas.Com. https:/ / nasional.kompas.com/read/2020/04/25/15472271/update-25-april-kasuscovid-19-di-indonesia-mencapai-8607

Agustin, N. M. (2015). Pola Pengasuhan Anak Usia Dini. Surabaya: Unesa University Press. Unesa University Press.

Akbar, Z. (2017). Program Peningkatan Keterlibatan Orangtua Melalui Kegiatan Seni Pada Anak Usia Dini. Sarwahita, 14(01), 53-60. https:/ / doi.org/10.21009/sarwahita.141.07

Aktaruzzaman, Md., Huq Shamim, R., \& Clement, C. K. (2011). Trends and Issues to integrate ICT in Teaching Learning for the Future World of Education. International Journal of Engineering \& Technology IJET-IJENS, 11(3), 114-119.

Apriliana, E. S. (2017). Pendampingan Anak dalam Keluarga di TK Pertiwi Kebasen Kabupaten Banyumas. Jurnal Elektronik Mahasiswa Pend. Luar Sekolah - S1, 287-298.

Arikunto, S. (2010). Prosedur Penelitian Satuan Pendekatan Praktik. Renika Cipta.

Basilaia, G., \& Kvavadze, D. (2020). Transition to Online Education in Schools during a SARSCoV-2 Coronavirus (COVID-19) Pandemic in Georgia. Pedagogical Research, 5(4). https://doi.org/10.29333/pr/7937

Baumrind, D. (1978). Parental disciplinary patterns and social competence in children. Youth $\mathcal{E}$ Society, 9(3), 239-267. https:/ / doi.org/10.1177/0044118X7800900302

BBC. (2020). Virus corona: "Status Kedaruratan Kesehatan Masyarakat" dan Pembatasan Sosial Berskala Besar, yang boleh dan tidak boleh-BBC News Indonesia. BBC News Indonesia. https://www.bbc.com/indonesia/indonesia-52109439

Chen, N., Zhou, M., Dong, X., Qu, J., Gong, F., Han, Y., Qiu, Y., Wang, J., Liu, Y., Wei, Y., Xia, J., Yu, T., Zhang, X., \& Zhang, L. (2020). Epidemiological and clinical characteristics of 99 cases of 2019 novel coronavirus pneumonia in Wuhan, China: A descriptive study. The Lancet, 395(10223), 507-513. https:/ / doi.org/10.1016/S0140-6736(20)30211-7

Dewantara, K. H. (1961). Ilmu Pendidikan. Taman Siswa.

Dewi, L. (2017). Rancangan Program Pembelajaran Daring Di Perguruan Tinggi: Studi Kasus Pada Mata Kuliah Kurikulum Pem-Belajaran Di Universitas Pendidikan Indonesia. Edutech, 16(2), 205. https:// doi.org/10.17509/e.v16i2.7616

Dewi, W. A. F. (2020a). Dampak COVID-19 terhadap Implementasi Pembelajaran Daring di Sekolah Dasar. Edukatif: Jurnal Ilmu Pendidikan, 2(1), 55-61. https://doi.org/10.31004/edukatif.v2i1.89

Dewi, W. A. F. (2020b). Dampak COVID-19 terhadap Implementasi Pembelajaran Daring di Sekolah Dasar. EDUKATIF: JURNAL ILMU PENDIDIKAN, 2(1), 55-61. https://doi.org/10.31004/edukatif.v2i1.89 
Diadha, R. (2015). Keterlibatan orang tua dalam pendidikan anak usia dini di taman kanakkanak. Edusentris, 2(1), 61. https:// doi.org/10.17509/edusentris.v2i1.161

Dian, K. (2020). Khofifah Perpanjang Masa Belajar Daring Siswa SMA/SMK - Surabaya Liputan6.com. Liputan 6.Com. https:/ / surabaya.liputan6.com/read/4267567/khofifahperpanjang-masa-belajar-daring-siswa-smasmk

Ditjen GTK. (2016). Petunjuk Teknis Program Peningkatan Guru Pembelajar Moda Dalam Jaring (Daring).

Djalante, R., Lassa, J., Setiamarga, D., Sudjatma, A., Indrawan, M., Haryanto, B., Mahfud, C., Sinapoy, M. S., Djalante, S., Rafliana, I., Gunawan, L. A., Surtiari, G. A. K., \& Warsilah, H. (2020). Review and analysis of current responses to COVID-19 in Indonesia: Period of January to March 2020. Progress in Disaster Science, 6, 100091. https:// doi.org/10.1016/j.pdisas.2020.100091

Epstein, J. L., \& Becker, H. J. (2018). Teachers' reported practices of parent involvement: Problems and possibilities. School, Family, and Community Partnerships, Student Economy Edition: Preparing Educators and Improving Schools, 83(2), 115-128. https:// doi.org/10.4324/9780429493133

Fitroturrohmah, M., \& Azizah, M. (2019). Hubungan peran orang tua dengan prestasi belajar siswa kelas tinggi sdn kedung 01 jepara. 2(September).

Gunawan, I., \& Palupi, A. R. (2016). Taksonomi bloom - revisi ranah kognitif: kerangka landasan untuk pembelajaran, pengajaran, dan penilaian. Premiere Educandum: Jurnal Pendidikan Dasar dan Pembelajaran, 2(02). https://doi.org/10.25273/pe.v2i02.50

Gutman, L. M., \& McLoyd, V. C. (2000). Parents' management of their children's education within the home, at school, and in the community: An examination of african-american families living in poverty. Urban Review, 32(1), 1-24. https:/ / doi.org/10.1023/A:1005112300726

Guy, B. (2014). Re-conceptualising commitments to sustainable development in the 21st century-nurturing action and accountability in the networked world. Economic and Social Review, 45(2), 223-244.

Haerudin, H., Cahyani, A., Sitihanifah, N., Setiani, R. N., Nurhayati, S., Oktaviana, V., \& Sitorus, Y. I. (2020). Peran Orangtua Dalam Membimbing Anak Selama Pembelajaran Di Rumah Sebagai Upaya Memutus Covid-19. Jurnal Stastistika Inferensial, 1-12.

Hamid, A. A. (2002). Hamid - $2001-E$-Learning. 4, 311-316.

Hobbs, V. (2011). US rural DL big report. Strategy, 01, 1-4.

Hollingworth, S., Mansaray, A., Allen, K., \& Rose, A. (2011). Parents' perspectives on technology and children's learning in the home: Social class and the role of the habitus. Journal of Computer Assisted Learning, 27(4), 347-360. https://doi.org/10.1111/j.13652729.2011.00431.x

Huang, C., Wang, Y., Li, X., Ren, L., Zhao, J., Hu, Y., Zhang, L., Fan, G., Xu, J., Gu, X., Cheng, Z., Yu, T., Xia, J., Wei, Y., Wu, W., Xie, X., Yin, W., Li, H., Liu, M., .. Cao, B. (2020). Clinical features of patients infected with 2019 novel coronavirus in Wuhan, China. The Lancet, 395(10223), 497-506. https:/ / doi.org/10.1016/S0140-6736(20)30183-5

Ingram, M., Wolfe, R. B., \& Lieberman, J. M. (2015). The Role of Parents in At-Risk Populations. 2002, 479-497.

Irvin, M. J., Hannum, W. H., Farmer, T. W., Varre, C. de la, \& Keane, J. (2018). Supporting Online Learning for Advanced Placement Students in Small Rural Schools. The Rural Educator, 31(1), 29-37. https:// doi.org/10.35608/ruraled.v31i1.440

Jimerson, L. (2006). Breaking the Fall: Cushioning the Impact of Rural Declining Enrollment. Rural Trust Policy Brief Series on Rural Education. Rural School and Community Trust, February.

Kementerian Komunikasi dan Informatika RI. (2019). Dinamika Data Aplikasi Informatika. Direktorat Jendral Aplikasi Informatika. 
DOI: 10.31004/obsesi.v5i2.740

Kurniati, E., Nur Alfaeni, D. K., \& Andriani, F. (2020). Analisis Peran Orang Tua dalam Mendampingi Anak di Masa Pandemi Covid-19. Jurnal Obsesi : Jurnal Pendidikan Anak Usia Dini, 5(1), 241. https:// doi.org/10.31004/obsesi.v5i1.541

Lai, C. C., Shih, T. P., Ko, W. C., Tang, H. J., \& Hsueh, P. R. (2020). Severe acute respiratory syndrome coronavirus 2 (SARS-CoV-2) and coronavirus disease-2019 (COVID-19): The epidemic and the challenges. International Journal of Antimicrobial Agents, 55(3), 105924. https://doi.org/10.1016/j.ijantimicag.2020.105924

Lilawati, A. (2020). Peran Orang Tua dalam Mendukung Kegiatan Pembelajaran di Rumah pada Masa Pandemi. Jurnal Obsesi: Jurnal Pendidikan Anak Usia Dini, 5(1), 549. https://doi.org/10.31004/obsesi.v5i1.630

Mann, M., Hosman, C. M. H., Schaalma, H. P., \& De Vries, N. K. (2004). Self-esteem in a broadspectrum approach for mental health promotion. Health Education Research, 19(4), 357372. https://doi.org/10.1093/her/cyg041

Martsiswati, E., \& Suryono, Y. (2014a). Peran Orang Tua Dan Pendidik Dalam Menerapkan Perilaku Disiplin Terhadap Anak Usia Dini. Jurnal Pendidikan Dan Pemberdayaan Masyarakat, 1(2), 187. https:/ / doi.org/10.21831/jppm.v1i2.2688

Martsiswati, E., \& Suryono, Y. (2014b). Peran orang tua dan pendidik dalam menerapkan perilaku disiplin terhadap anak usia dini. Jurnal Pendidikan dan Pemberdayaan Masyarakat, 1(2), 187. https:/ / doi.org/10.21831/jppm.v1i2.2688

Mauanah, S. (2016). Parenting Education Sebagai Pendidikan Keluarga. Paradigma, 04(2), 1-10.

Menheere, A., \& Hooge, E. (2010). Parental involvement in children's education: A reviewstudy about the effect of parental involvement on children's school education with a focus on the position of illiterate parents. Journal of the European Teacher Education Network JETEN, 6(January 2010), 157.

Mirzon Daheri, Juliana, Deriwanto, A. D. A. (2020). Jurnal basicedu. Jurnal Basicedu, 3(2), 524 532. https:// doi.org/10.31004/basicedu.v4i4.445

Muhammad, H., Rahim, Y., Pendidikan, J., Islam, A., Tarbiyah, F., Uin, K., Makassar, A., Btn, A. :, \& Makassar, A. (2011). Pemanfaatan Ict Sebagai Media Pembelajaran Dan Informasi Pada Uin Alauddin Makassar. 6(3), 127-135.

Noble, K. G., Houston, S. M., Brito, N. H., Bartsch, H., Kan, E., Kuperman, J. M., Akshoomoff, N., Amaral, D. G., Bloss, C. S., Libiger, O., Schork, N. J., Murray, S. S., Casey, B. J., Chang, L., Ernst, T. M., Frazier, J. A., Gruen, J. R., Kennedy, D. N., Van Zijl, P., ... Sowell, E. R. (2015). Family income, parental education and brain structure in children and adolescents. Nature Neuroscience, 18(5), 773-778. https:// doi.org/10.1038/nn.3983

Novrinda, Nina Kurniah, Y. (2017). Peran Orang Tua Dalam Pendidikan Anak Usia Dini ditinjau dari latar belakang pendidikan Novrinda. Raudhatul Athfal: Jurnal Pendidikan Islam Anak Usia Dini, 1(1), 61-80. https:/ / doi.org/10.19109/ ra.v1i1.1526

Okmawati, M., \& Tanjak, D. (2011). Journal of English Language Teaching the use of google classroom during pandemic. 9(2).

Pangondian, R. A., Santosa, P. I., \& Nugroho, E. (2019). Faktor - Faktor Yang Mempengaruhi Kesuksesan Pembelajaran Daring Dalam Revolusi Industri 4.0. Seminar Nasional Teknologi Komputer \& Sains (SAINTEKS), 1(1), 56-60.

Patmodewo, S. (2003). Pendidikan Anak Prasekolah. Renika Cipta.

Pebriansyah, A. (2020). Surat Edaran Virus Corona Wali Kota Surabaya: Hentikan Posyandu BalitaBagian 1. Suarajatim.Id. https://jatim.suara.com/read/2020/03/22/120334/suratedaran-virus-corona-wali-kota-surabaya-hentikan-posyandu-balita

Peterson, S. M., Valk, C., Baker, A. C., Brugger, L., \& Hightower, A. D. (2010). “we're not just interested in the work": Social and emotional aspects of early educator mentoring relationships. Mentoring and Tutoring: Partnership in Learning, 18(2), 155-175. https://doi.org/10.1080/13611261003678895

Purwanto, A., Asbari, M., Fahlevi, M., Mufid, A., Agistiawati, E., Cahyono, Y., \& Suryani, P. (2020). Impact of Work From Home (WFH) on Indonesian Teachers Performance 
During the Covid-19 Pandemic: An Exploratory Study. International Journal of Advanced Science and Technology, 29(5), 6235-6244.

Purwanto, A. E., \& Hendri, M. (2016). Studi perbandingan hasil belajar siswa menggunakan media phet simulations dengan alat peraga pada pokok bahasan listrik magnet di kelas ix smpn 12 kabupaten tebo. Jurnal Pendidikan Fisika, 01(01), 6.

Retno, A. (2013). Hubungan Intensitas Pendampingan Belajar Orang Tua dengan Kualitas Hasil Belajar Siswa di Ra Al-Islam Mangunsari 02 Semarang Tahun Pelajaran 2011/2012. Indonesian Journal of Early Childhood Education Studies, 2(2), 43-49. https:// doi.org/10.15294/ijeces.v2i2.9240

Sisdiknas. (2003). Undang-undang Republik Indonesia Tentang Sistem Pendidikan Nasional Nomor 20 Tahun 2003.

Slameto. (2010). Belajar dan Faktor-Faktor yang Mempengaruhinya. Edisi Revisi. PT. Rineka Cipta. Sudaryono. (2014). Teori dan Aplikasi dalam Statistik. CV. Andi Offset.

Sudjana, Djudju. (2004). Manajemen Program Pendidikan; Untuk Program Pendidikan Non Formal dan Pengembangan Sumber Daya Manusia. Falah Production.

Sugiyono. (2017). Metode Penelitian Pendidikan: Pendekatan Kuantitatif, Kualitatif, R\&D. Cetakan Ke-25. Bandung: CV Alfabeta.

Suyadi. (2010). Psikologi Belajar PAUD. Pedagogia.

Trisnawati, W., \& Sugito, S. (2020). Pendidikan Anak dalam Keluarga Era Covid-19. Jurnal Obsesi: Jurnal Pendidikan Anak Usia Dini, 5(1), 823-831. https:// doi.org/10.31004/obsesi.v5i1.710

Wyatt Kaminski, J., Valle, L. A., Filene, J. H., \& Boyle, C. L. (2008). A meta-analytic review of components associated with parent training program effectiveness. Journal of Abnormal Child Psychology, 36(4), 567-589. https:// doi.org/10.1007/s10802-007-9201-9

Yovita, A. (2020). Lebih dari 849 Juta Siswa di Dunia Belajar di Rumah - Kompas.id. Kompas.Id. https:/ / kompas.id/baca/humaniora/dikbud/2020/03/18/lebih-dari-849-juta-siswadi-dunia-belajar-di-rumah/

Yusuf, A. M. (2016). Metode Penelitian Kuantitatif, Kualitatif \& Penelitian Gabungan. Prenada Media. 